\title{
Inhibitory effects of heat shock protein 90 blockade on proinflammatory human Th1 and Th17 cell subpopulations
}

\author{
Stefan Tukaj, Detlef Zillikens and Michael Kasperkiewicz
}

\begin{abstract}
Background: Heat shock protein 90 (Hsp90), a chaperone that regulates activity of many client proteins responsible for cellular growth, differentiation, and apoptosis, has been proposed as an important clinical and preclinical therapeutic target in a number of malignancies and autoimmune diseases, respectively. In this study, we evaluated the effects of pharmacological Hsp90 inhibition on human proinflammatory T cell responses.

Findings: Using anti-CD3 antibody-stimulated human peripheral blood mononuclear cell cultures, we observed that Hsp90 inhibition by non-toxic concentrations of the geldanamycin derivative 17-DMAG significantly blocked T cell proliferation, reduced IFN- $\gamma$ and IL-17 expression on $\mathrm{CD}^{+} \mathrm{T}$ lymphocytes, and arrested secretion of proinflammatory IFN- $\gamma$, TNF-a, and IL-17, cytokines characteristic of Th1 and Th17 cells, respectively. These effects were associated with inhibition of NF-kB activity, upregulation of Hsp70 protein expression, and disruption of T cell-specific nonreceptor tyrosine kinase Lck activation.
\end{abstract}

Conclusions: Our results further support the potential use of Hsp90 inhibitors in patients with autoimmune diseases where uncontrolled Th1 or Th17 activation frequently occurs.

Keywords: 17-DMAG, Heat shock protein, T cell

\section{Introduction}

Heat shock protein 90 (Hsp90) is an ATP-dependent molecular chaperone that is exploited by malignant cells to support activated oncoproteins, including many cancer-associated kinases and transcription factors, but has been also shown to exert potent immunomodulatory actions [1,2].

Several pieces of evidence show that Th1 and Th17 cells are pathophysiologically associated with several autoimmune diseases and that Hsp90 activity is required for IFN- $\gamma$ and IL-17 signaling in these cell types, respectively [3-5]. Based on these findings and the observations that Hsp90 plays important roles in antigen presentation, activation of lymphocytes, macrophages, and dendritic cells [2], we and others claim that pharmacological inhibition of Hsp90 is a promising therapy to ameliorate inflammatory cascades in autoimmune diseases [6-11].

\footnotetext{
*Correspondence: Michael.Kasperkiewicz@uk-sh.de

Department of Dermatology, University of Lübeck, Ratzeburger Allee 160, 23538 Lübeck, Germany
}

In the present study, we show that blockade of Hsp90 by the geldanamycin derivative 17-DMAG leads to inhibition of $\mathrm{T}$ cell proliferation, suppression of IFN- $\gamma$ and IL-17 expression on $\mathrm{CD}^{+}{ }^{+} \mathrm{T}$ cells, and attenuation of secretion of proinflammatory IFN- $\gamma$, TNF- $\alpha$, and IL-17, cytokines characteristic of Th1 and Th17 cells, respectively.

\section{Methods}

\section{Cell culture}

Peripheral blood mononuclear cells (PBMCs) were isolated from venous blood of 11 healthy volunteers (age 25-35 years, mean $29.72 \pm 3.47,6$ females and 5 males) by Ficoll-Paque (GE Healthcare Bio-Sciences) gradient centrifugation and cultured as described previously with minor modification [12]. Briefly, PBMCs were washed twice in PBS and resuspended at $0.5 \times 10^{5}$ or $1 \times 10^{6}$ cells per ml of medium (RPMI 1640 supplemented with $10 \%$ fetal calf serum, $2 \mathrm{mM}$ L-glutamine, and penicillin/ streptomycin). Cells were cultured in the presence of $1 \mu \mathrm{g} / \mathrm{ml}$ immobilized anti-CD3 mAb (BD Bioscience) in 
24-well or 96-well culture plates in $5 \% \mathrm{CO}_{2}$ at $37^{\circ} \mathrm{C}$ without or with different concentration of 17-DMAG (InVitrogen) for 24 hours, 72 hours, or 7 days.

The collection of blood samples was approved by the Ethics Committee of the University of Lübeck, and informed consent was obtained according to the Declaration of Helsinki.

\section{LDH cytotoxicity assay}

Cytotoxicity of 17-DMAG was measured by a lactate dehydrogenase (LDH)-releasing assay using a Cytotoxicity Detection Kit (Roche) according to the manufacturer's protocol and quantified using an ELISA plate reader. Briefly, PBMCs $\left(1 \times 10^{6}\right.$ per $\left.\mathrm{ml}\right)$ were incubated with 17 DMAG at different concentrations $(0.1,1$, and $2.5 \mu \mathrm{M})$ for 24 hours. Cell lysis was determined by measuring the amount of $\mathrm{LDH}$ released into the culture medium.

\section{Proliferation assay}

A total of $0.5 \times 10^{5}$ PBMCs were cultured in the presence of plate-bound anti-CD3 mAb in 96-well plates. Stimulated cells were cultured alone or with different concentrations of 17-DMAG $(0.1,1$, or $2.5 \mu \mathrm{M})$. After 6 days, cells were pulsed with BrdU for further 24 hours. $\mathrm{T}$ cell proliferation was measured using a colorimetric cell proliferation BrdU ELISA (Roche).

\section{Flow cytometric immunophenotyping}

For analysis of intracellular cytokines, PBMCs were stimulated with anti-CD3 mAb without or with 17DMAG $(0.1 \mu \mathrm{M})$ for $72 \mathrm{~h}$ hours. A GolgiStop ${ }^{\mathrm{Tm}}$ Protein Transport Inhibitor (BD Pharmingen ${ }^{\mathrm{TM}}$ ) was added together with phorbol-12-myristate-13-acetate (PMA) (50 $\mathrm{ng} / \mathrm{ml})$ and ionomycin $(1 \mu \mathrm{g} / \mathrm{ml})$ (Sigma) for the last 5 hours. Cells were washed, fixed, permeabilized, and stained for detection of intracellular cytokines using the following anti-human mAbs: anti-IFN- $\gamma$-FITC, anti-IL17-PE, and anti-CD4-PERCP-CY5.5 (BD Pharmingen). Samples were analyzed using FACSCalibur flow cytometer (BD).

\section{Cytokine measurement}

Supernatants of PBMC cultures were collected after a 72-hour treatment period with anti-CD3 mAb in absence or presence of 17-DMAG $(0.1 \mu \mathrm{M})$. Supernatants were taken from cultures non-treated by GolgiStop, PMA, or ionomycin. Twelve cytokines (IL-2, IL-4, IL-5, IL-6, IL-10, IL-12, IL-13, IL-17A, IFN- $\gamma$, TNF- $\alpha$, G-CSF, and TGF- 31 ) were measured by a Human Th1/Th2/ Th17 Cytokines Multi-Analyte ELISArray Kit (Qiagen Biosciences).

\section{Determination of NFKB p65 activity}

For analysis of NFkB p65 activity, PBMCs were stimulated with anti-CD3 mAb without or with different concentrations of 17-DMAG $(0.1,1$, and $2.5 \mu \mathrm{M})$ for 24 hours. NFkB p65 activity was measured in cell lysates by a NFkB p65 ELISA kit following the manufacturer's instruction (Enzo).

\section{Immunoblotting}

Equal amounts of PBMC lysates were separated by $10 \%$ SDS-PAGE gel and transferred onto nitrocellulose membrane. The membrane was blocked with 3\% milk in PBS for 2 hours, followed by incubation with rabbit polyclonal antibodies against NFKB p65 (1:1000; Santa Cruz Biotechnology, Inc.), Hsp70 (1:100; Stressgen), p-Lck $\left(\mathrm{Tyr}^{394}\right)$ (1:1000; Sigma), and $\beta$-actin (1:1000; Cell Signaling Technology) at room temperature for 2 hours. Horseradish peroxidase-conjugated gout anti-rabbit antibodies (1:1000; Dako) were used as secondary antibodies. The bands were visualized using Amersham ECL Plus Western Blotting Detection Reagents (GE Healthcare). Relative $\mathrm{NF}_{\mathrm{KB}} \mathrm{p} 65$, Hsp70, and p-Lck $\left(\mathrm{Tyr}^{394}\right.$ ) protein concentrations were measured by densitometry.

\section{Statistical analysis}

Data was analyzed by Student's t-test or one-way analysis of variance (ANOVA) using Graphpad prism 5 (San Diego, California). A $P$-value $<0.05$ was considered to indicate a statistically significant difference.

\section{Results}

17-DMAG arrests proliferation of T cells

To determine whether 17-DMAG affects T cell proliferation, we isolated human PBMCs from healthy volunteers and stimulated them with anti-CD3 antibody in the absence or presence of different amounts of 17-DMAG. Cell proliferation was assayed by BrdU ELISA. T cell proliferation was inhibited by 17-DMAG in a dosedependent manner (Figure 1A) and this inhibitory effect was observed upon non-toxic concentrations of the inhibitor (Figure 1B).

\section{7-DMAG inhibits proinflammatory Th1 and Th17 cell subpopulations}

Next, we investigated the effects of 17-DMAG on proinflammatory $\mathrm{T}$ cell subpopulations $\left[\mathrm{CD} 4^{+} \mathrm{IFN}-\gamma^{+}\right.$(Th1) and $\mathrm{CD}^{+}{ }^{+} \mathrm{IL}-17^{+}$(Th17)] using flow cytometry. We observed that 17-DMAG significantly inhibited intracellular expression of IFN- $\gamma$ and IL-17A in anti-CD3 antibody-treated PBMCs, representing Th1 and Th17 cell fractions, respectively (Figure 2). 


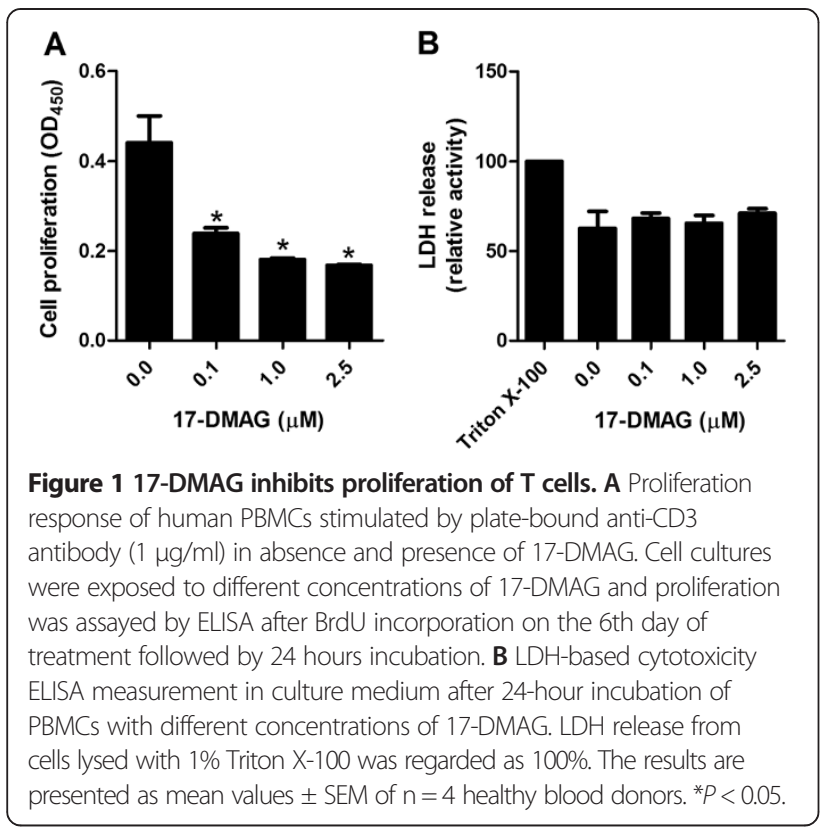

\section{7-DMAG dampens the secretion of proinflammatory} cytokines

Using ELISA, we further measured the effects of 17 DMAG on secretion of a broad array of PBMC-derived cytokines (IL-2, IL-4, IL-5, IL-6, IL-10, IL-12, IL-13, IL-
$17 \mathrm{~A}, \mathrm{IFN}-\gamma, \mathrm{TNF}-\alpha, \mathrm{G}-\mathrm{CSF}$, and TGF- $\beta 1)$. The cytokines were assayed in culture medium of PBMCs stimulated with anti-CD3 antibody. The presence of 17-DMAG significantly inhibited the secretion of the proinflammatory cytokines IFN- $\gamma$ (4.2-fold), TNF- $\alpha$ (2.8-fold), and IL-17A (1.5-fold). We found no significant influence of 17DMAG on IL-2, G-CSF, and TGF- $\beta 1$ secretion. The remaining cytokines were below the detection limit of the assay (Figure 3).

\section{7-DMAG suppresses NFkB p65 activity}

To test whether Hsp90 inhibition had an impact on NFkB p65, its activity as well as protein expression was measured in cell lysates of anti-CD3 antibody-stimulated PBMCs by ELISA and immunoblotting, respectively. Our results revealed that the addition of 17-DMAG dose-dependently suppressed NFkB p65 activity without affecting its protein level (Figure 4).

\section{7-DMAG upregulates Hsp70 expression}

To investigate whether 17-DMAG influenced the expression of Hsp70, a common marker of Hsp90 inhibition, immunoblot analysis of lysates from anti-CD3 antibody-stimulated PBMCs was performed. Indeed, the addition of 17-DMAG to these cell cultures resulted in induction of Hsp70 protein expression (Figure 5).

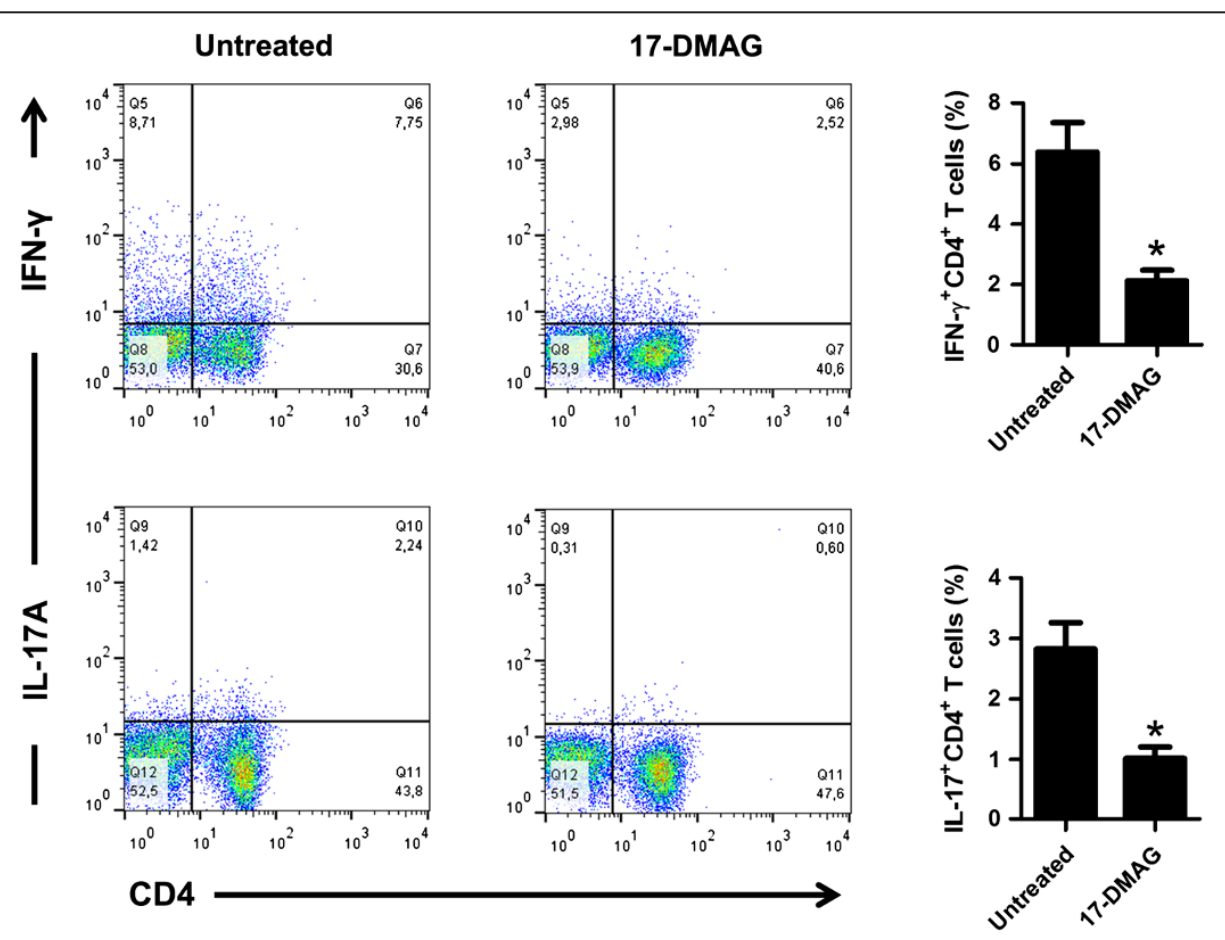

Figure 2 17-DMAG reduces frequencies of proinflammatory Th1 and Th17 cell subpopulations. PBMCs were stimulated with $1 \mu \mathrm{g} / \mathrm{ml}$ of plate-bound anti-CD3 antibody in absence or presence of 17-DMAG $(0.1 \mu \mathrm{M})$ for 72 hours. GolgiStop ${ }^{\mathrm{TM}}$, PMA, and ionomycin were added in the last 5 hours of culture before permeabilization. Cells were washed, stained with anti-CD4, anti-IFN- $\gamma$, and anti-IL-17 antibodies, and analyzed by flow cytometry. The numbers in upper right quadrants of the representative dot blots show the percentage of positive cells of each CD4 ${ }^{+} \mathrm{T}$ cell subpopulation. The results are presented as mean values \pm SEM of $n=4$ healthy blood donors. ${ }^{*} P<0.05$. 


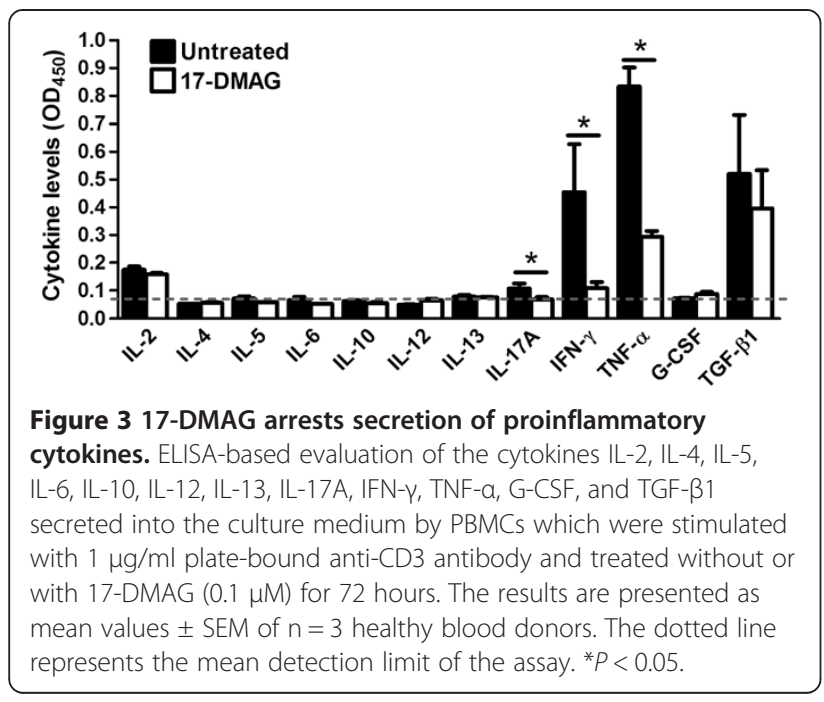

17-DMAG blocks Lck phosphorylation

To examine whether Hsp90 inhibition had an impact on $\mathrm{T}$ cell-specific nonreceptor tyrosine kinase Lck, its phosphorylation status was measured in cell lysates of antiCD3 antibody-stimulated PBMCs by immunoblotting. We demonstrated that the addition of 17-DMAG dosedependently suppressed Lck activation (Figure 6).

\section{Discussion}

Here, we provide evidence that 17-DMAG, upon nontoxic concentrations, inhibited $\mathrm{T}$ cell proliferation and reduced percentages of Th1 and Th17 cells, which was associated with dampened Th1 (IFN- $\gamma$ and TNF- $\alpha$ ) and Th17 (IL-17) cytokine secretion. These results are in good agreement with previous studies reporting the capacity of Hsp90 blockers to inhibit proliferation of $\mathrm{T}$ lymphocytes ex vivo and to downregulate these proinflammatory $\mathrm{T}$ cell subtypes $[4-11,13]$.

Since Th1 and Th17 cells are essential to the development of various autoimmune diseases, treatment strategies which aim at blocking of uncontrolled activation of such effector cell populations are highly warranted [3]. In fact, pharmacological blockade of Hsp90 has been reported to be an effective treatment in rodent models of $\mathrm{T}$ cell-mediated autoimmune diseases, such as autoimmune encephalomyelitis [6], rheumatoid arthritis $[7,8]$, and systemic lupus erythematosus $[9,10]$. In addition, our research group recently demonstrated that, by downregulating $\mathrm{T}$ cell responses, treatment with Hsp90 inhibitors is also effective in mice with the experimentally induced autoimmune bullous disease epidermolysis bullosa acquisita [11].

Although the main focus of our experiments was to study the impact of 17-DMAG on Th1 and Th17 subpopulations, we cannot rule out but also not support that 17DMAG additionally exhibited suppressive activity on

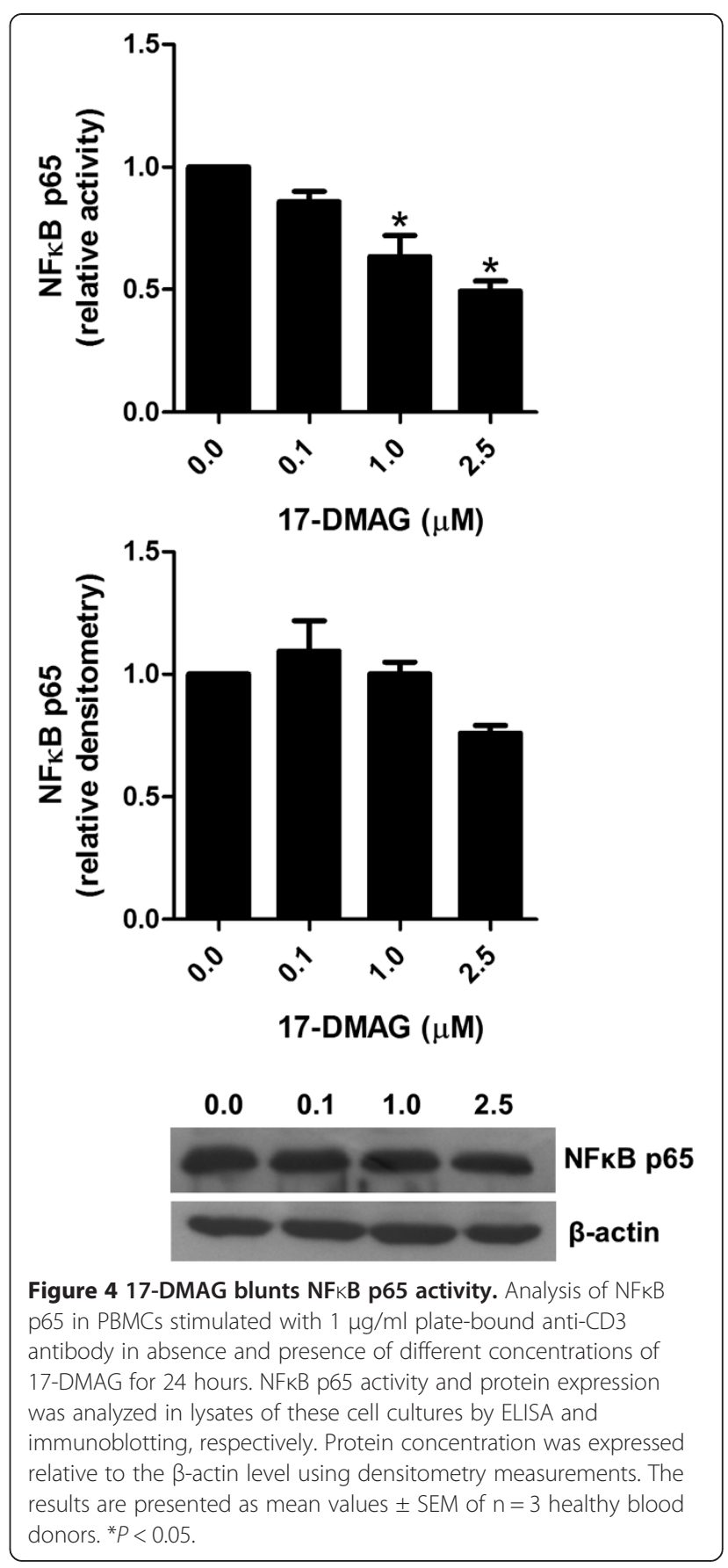

other $\mathrm{T}$ cell populations such as Th2 and regulatory $\mathrm{T}$ cells since Th2 cytokines released from anti-CD3 antibody-stimulated PBMCs were below the detection limit of our assay and secreted IL-10 and TGF- $\beta 1$, cytokines associated with regulatory $\mathrm{T}$ cell function, were also undetectable or not significantly inhibited in our study, respectively. In this context, it is worth noting that there is evidence in the recent literature that Hsp90 inhibition can promote rather than inhibit regulatory $\mathrm{T}$ cells, further supporting an antiinflammatory mechanism of 

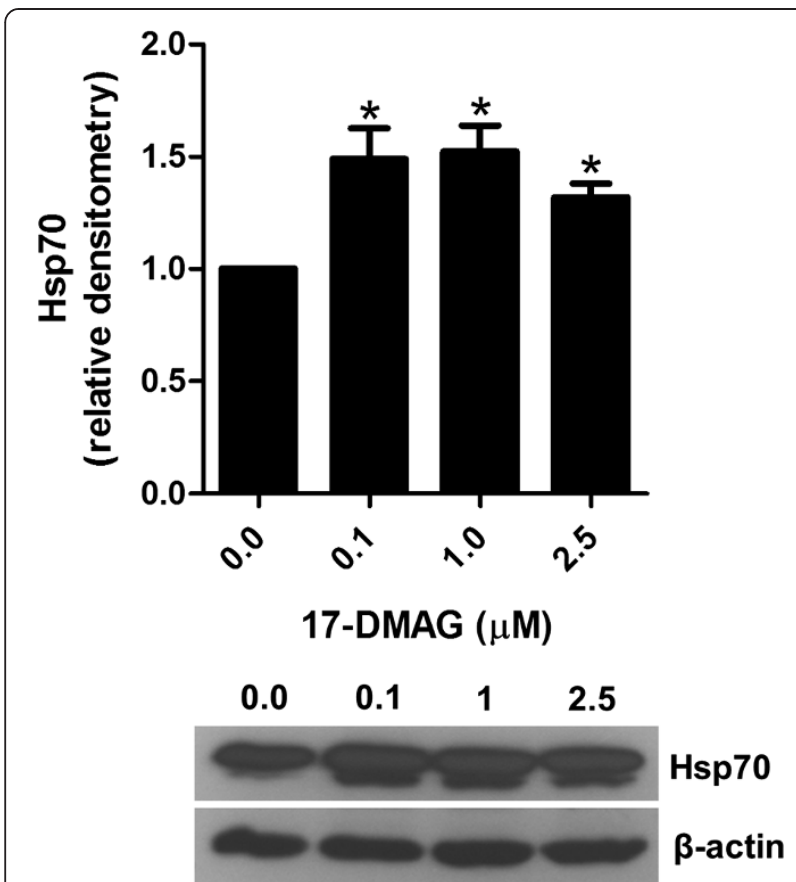

Figure 5 17-DMAG induces Hsp70 expression. Analysis of Hsp70 in PBMCs stimulated with $1 \mu \mathrm{g} / \mathrm{ml}$ plate-bound anti-CD3 antibody in absence and presence of different concentrations of 17-DMAG for 24 hours. Hsp70 protein expression was analyzed in cell lysates of these cell cultures by immunoblotting. Protein concentration was expressed relative to the $\beta$-actin level using densitometry measurements. The results are presented as mean values \pm SEM of $\mathrm{n}=3$ healthy blood donors. ${ }^{*} \mathrm{P}<0.05$.

action of Hsp90 blockers in terms of $\mathrm{T}$ cell responses $[14,15]$.

Our current experiments further revealed that inhibition of T cells by 17-DMAG was associated with deactivation of $\mathrm{NF} \mathrm{B}$ and upregulation of Hsp70. While $\mathrm{NF \kappa B}$ is a client of Hsp90 and one of the major transcription factors responsible for proliferation of $\mathrm{T}$ cells and their proinflammatory IFN- $\gamma$ and IL-17 expression [16,17], Hsp70 is generally considered as a marker for effective Hsp90 inhibition and also regarded as potent antiinflammatory chaperone capable of inhibiting $N F \kappa B$ signaling pathways [18-20].

Corticosteroids, which are widely used to treat patients with autoimmune diseases, mediate their immunosuppressive effects through cytosolic ligand-inducible glucocorticoid receptors. Inactive glucocorticoid receptors are associated with (co)chaperones, including Hsp90, which dissociate after their ligation, followed by nuclear translocation of these receptors and regulation of gene transcription [21]. The glucocorticoid receptor has been described as part of a $\mathrm{T}$ cell receptor-linked multiprotein complex containing Hsp90 and the nonreceptor tyrosin kinases Lck and Fyn, which is essential for $\mathrm{T}$ cell receptor-dependent Lck/Fyn activation. It has been

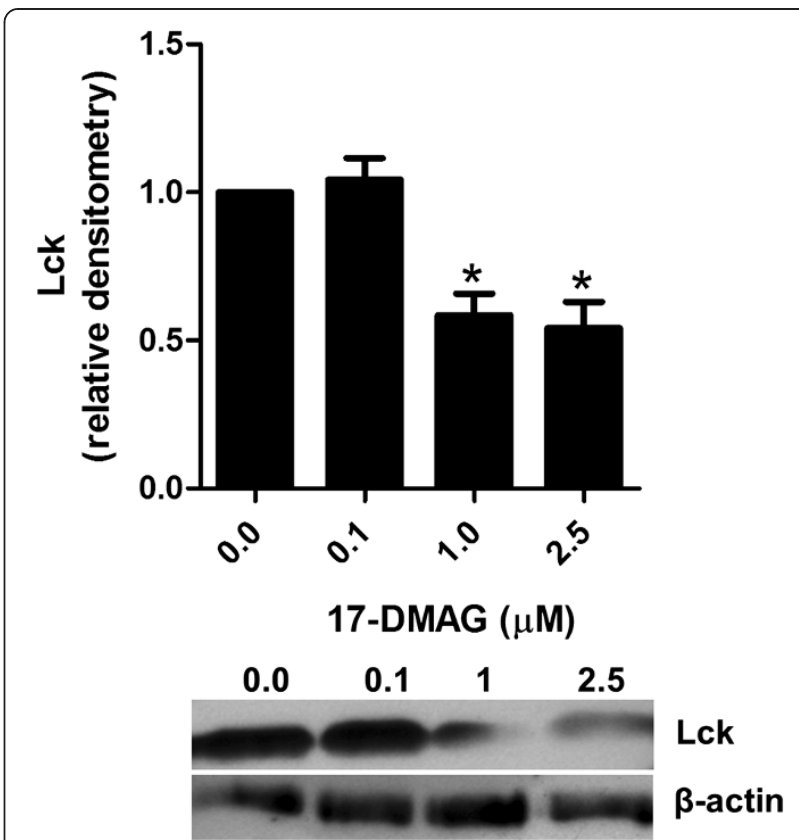

Figure 6 17-DMAG disrupts Lck activation. Analysis of Lck in PBMCs stimulated with $1 \mu \mathrm{g} / \mathrm{ml}$ plate-bound anti-CD3 antibody in absence and presence of different concentrations of 17-DMAG for 24 hours. Lck phosphorylation at Tyr ${ }^{394}$ position was analyzed in lysates of these cell cultures by immunoblotting. Protein concentration was expressed relative to the $\beta$-actin level using densitometry measurements. The results are presented as mean values \pm SEM of $n=3$ healthy blood donors. ${ }^{*} P<0.05$.

previously shown that either treatment with dexamethasone or knocking down Hsp90 by Hsp90siRNA induces dissociation of this protein complex, resulting in abrogated $\mathrm{T}$ cell receptor signaling as a consequence of impaired Lck/Fyn activation [22]. Similar to this and other previous studies $[4,13,22]$, we could show in the current experiments that pharmacological blockade of Hsp90 was associated with inhibition of Lck activation in antiCD3 antibody-stimulated PBMCs, a mechanism that could further account for the observed immunosuppressive effects of this treatment on T cells.

Considering that inhibition of both NF-kB function and proximal $\mathrm{T}$ cell receptor signaling by corticosteroids can be mimicked using Hsp90 inhibitors and that a novel generation of Hsp90 blockers with good tolerability has been reported in the field of cancer treatment $[4,13,22-25]$, it remains to be clarified in the future whether this class of drugs can potentially represent an effective alternative for corticosteroid therapy with a better side effect profile in patients with autoimmune diseases.

Together, our results further support the potential use of Hsp90 inhibitors in patients with autoimmune diseases where inappropriate activation of proinflammatory Th1 and Th17 subpopulations frequently occurs. 


\section{Competing interests}

The authors declare that they have no competing interests.

\section{Authors' contributions}

ST conceived the study, designed experiments, performed research, analyzed data, and wrote the manuscript. DZ analyzed data and contributed to composition of the paper. MK helped conceive of the study, design experiments, and write the manuscript. All authors read and approved the final manuscript.

\section{Acknowledgements}

This work was supported by Deutsche Forschungsgemeinschaft (DFG) Excellence Cluster "Inflammation at Interfaces" (EXC 306/2), DFG KA 3438/1-1, Medical Faculty of the University of Lübeck (E22-2013), and Focus Program

"Autoimmunity" at the University of Lübeck.

Received: 21 November 2013 Accepted: 24 March 2014

Published: 2 April 2014

\section{References}

1. Taipale M, Jarosz DF, Lindquist S: HSP90 at the hub of protein homeostasis: emerging mechanistic insights. Nat Rev Mol Cell Biol 2010, 11:515-528

2. Srivastava P: Roles of heat-shock proteins in innate and adaptive immunity. Nat Rev Immunol 2002, 2:185-194.

3. Ulivieri C, Baldari CT: T-cell-based immunotherapy of autoimmune diseases. Expert Rev Vaccines 2013, 12:297-310.

4. Bae J, Munshi A, Li C, Samur M, Prabhala R, Mitsiades C, Anderson KC, Munshi NC: Heat shock protein 90 is critical for regulation of phenotype and functional activity of human T lymphocytes and NK cells. J Immunol 2013, 190:1360-1371.

5. Wang C, Wu L, Bulek K, Martin BN, Zepp JA, Kang Z, Liu C, Herjan T, Misra S, Carman JA, Gao J, Dongre A, Han S, Bunting KD, Ko JS, Xiao H, Kuchroo VK, Ouyang W, Li X: The psoriasis-associated D10N variant of the adaptor Act1 with impaired regulation by the molecular chaperone hsp90. Nat Immunol 2013, 14:72-81.

6. Dello Russo C, Polak PE, Mercado PR, Spagnolo A, Sharp A, Murphy P, Kamal A, Burrows FJ, Fritz LC, Feinstein DL: The heat-shock protein 90 inhibitor 17-allylamino-17-demethoxygeldanamycin suppresses glial inflammatory responses and ameliorates experimental autoimmune encephalomyelitis. J Neurochem 2006, 99:1351-1362.

7. Rice JW, Veal JM, Fadden RP, Barabasz AF, Partridge JM, Barta TE, Dubois LG, Huang KH, Mabbett SR, Silinski MA, Steed PM, Hall SE: Small molecule inhibitors of Hsp90 potently affect inflammatory disease pathways and exhibit activity in models of rheumatoid arthritis. Arthritis Rheum 2008, 58:3765-3775

8. Yun TJ, Harning EK, Giza K, Rabah D, Li P, Arndt JW, Luchetti D, Biamonte MA, Shi J, Lundgren K, Manning A, Kehry MR: EC144, a synthetic inhibitor of heat shock protein 90 , blocks innate and adaptive immune responses in models of inflammation and autoimmunity. I Immunol 2011, 186:563-575.

9. Han JM, Kwon NH, Lee JY, Jeong SJ, Jung HJ, Kim HR, Li Z, Kim S: Identification of gp96 as a novel target for treatment of autoimmune disease in mice. PLoS One 2010, 5:e9792.

10. Shimp SK 3rd, Chafin CB, Regna NL, Hammond SE, Read MA, Caudell DL, Rylander M, Reilly CM: Heat shock protein 90 inhibition by 17-DMAG lessens disease in the MRL/lpr mouse model of systemic lupus erythematosus. Cell Mol Immunol 2012, 9:255-266.

11. Kasperkiewicz M, Müller R, Manz R, Magens M, Hammers CM, Somlai C, Westermann J, Schmidt E, Zillikens D, Ludwig RJ, Orosz A: Heat-shock protein 90 inhibition in autoimmunity to type VII collagen: evidence that nonmalignant plasma cells are not therapeutic targets. Blood 2011, 117:6135-6142.

12. Tukaj S, Kleszczyński K, Vafia K, Groth S, Meyersburg D, Trzonkowski P, Ludwig RJ, Zillikens D, Schmidt E, Fischer TW, Kasperkiewicz M: Aberrant expression and secretion of heat shock protein 90 in patients with bullous pemphigoid. PLoS One 2013, 8:e70496.

13. Yorgin PD, Hartson SD, Fellah AM, Scroggins BT, Huang W, Katsanis E, Couchman JM, Matts RL, Whitesell L: Effects of geldanamycin, a heat-shock protein 90-binding agent, on T cell function and T cell nonreceptor protein tyrosine kinases. J Immunol 2000, 164:2915-2923.
14. De Zoeten EF, Wang L, Butler K, Beier UH, Akimova T, Sai H, Bradner JE, Mazitschek R, Kozikowski AP, Matthias P, Hancock WW: Histone deacetylase 6 and heat shock protein 90 control the functions of Foxp3(+) T-regulatory cells. Mol Cell Biol 2011, 31:2066-2078.

15. Collins CB, Aherne CM, Yeckes A, Pound K, Eltzschig HK, Jedlicka P, De Zoeten EF: Inhibition of N-terminal ATPase on HSP90 attenuates colitis through enhanced Treg function. Mucosal Immunol 2013, 6:960-971.

16. Salminen A, Paimela T, Suuronen T, Kaarniranta K: Innate immunity meets with cellular stress at the IKK complex: regulation of the IKK complex by HSP70 and HSP90. Immunol Lett 2008, 117:9-15.

17. Oh H, Ghosh S: NF-kB: roles and regulation in different CD4(+) T-cell subsets. Immunol Rev 2013, 252:41-51.

18. Dakappagari N, Neely L, Tangri S, Lundgren K, Hipolito L, Estrellado A, Burrows $F$, Zhang $H$ : An investigation into the potential use of serum $\mathrm{Hsp} 70$ as a novel tumour biomarker for Hsp90 inhibitors. Biomarkers 2010, 5:31-38.

19. Stocki $P$, Dickinson AM: The immunosuppressive activity of heat shock protein 70. Autoimmune Dis 2012, 2012:617213.

20. De Jong PR, Schadenberg AW, Jansen NJ, Prakken BJ: Hsp70 and cardiac surgery: molecular chaperone and inflammatory regulator with compartmentalized effects. Cell Stress Chaperones 2009, 14:117-131.

21. Pratt WB, Galigniana MD, Morishima Y, Murphy PJ: Role of molecular chaperones in steroid receptor action. Essays Biochem 2004, 40:41-58.

22. Löwenberg M, Verhaar AP, Bilderbeek J, Marle J, Buttgereit F, Peppelenbosch MP, Van Deventer SJ, Hommes DW: Glucocorticoids cause rapid dissociation of a T-cell-receptor-associated protein complex containing LCK and FYN. EMBO Rep 2006, 7:1023-1029.

23. Celec P: Nuclear factor kappa B-molecular biomedicine: the next generation. Biomed Pharmacother 2004, 58:365-371.

24. Orosz A, Szabo A, Szeman G, Janaky T, Somlai C, Penke B, Bodor A, Perczel $A$ : Novel nontoxic heat shock protein 90 inhibitors having selective antiproliferative effect. Int J Biochem Cell Biol 2006, 38:1352-1362.

25. Garcia-Carbonero R, Carnero A, Paz-Ares L: Inhibition of HSP90 molecular chaperones: moving into the clinic. Lancet Oncol 2013, 14:e358-e369.

\section{doi:10.1186/1476-9255-11-10}

Cite this article as: Tukaj et al:: Inhibitory effects of heat shock protein 90 blockade on proinflammatory human Th1 and Th17 cell subpopulations. Journal of Inflammation 2014 11:10.

\section{Submit your next manuscript to BioMed Central and take full advantage of:}

- Convenient online submission

- Thorough peer review

- No space constraints or color figure charges

- Immediate publication on acceptance

- Inclusion in PubMed, CAS, Scopus and Google Scholar

- Research which is freely available for redistribution 